Revista Iberoamericana. Vol. LXIV, Núms. 184-185, Julio-Diciembre 1998; 413-439

\title{
EL ENTIERRO DE GONZÁLEZ: CON(TRA)FIGURACIONES DEL 98 EN LA NARRATIVA OCHENTISTA PUERTORRIQUEÑA
}

\author{
POR \\ César A. Salgado \\ The University of Texas at Austin
}

La fotografia exuda una curiosa seriedad funeraria. ${ }^{1}$ Se congrega alrededor del féretro lo más destacado del quehacer literario puertorriqueño. Alfrente están los egregios correligionarios de la generación, con atuendos propios para la ocasión, frontal la dolida mirada, postura de duelo militar. Soto tiene la expresión algo perdida en la evocación; los ojos de Valcárcel registran mejor la amargura de tamaña pérdida. Entre ellos, el ataúd luce una maciza enormidad que corresponde a la del hombre adentro. Detrás están los "jóvenes" de la generación siguiente, discípulos declarados. Con las manos cruzadas sobre el rigor de su luto, Arturo demuestra una suave tristeza. A pesar de asumir la misma

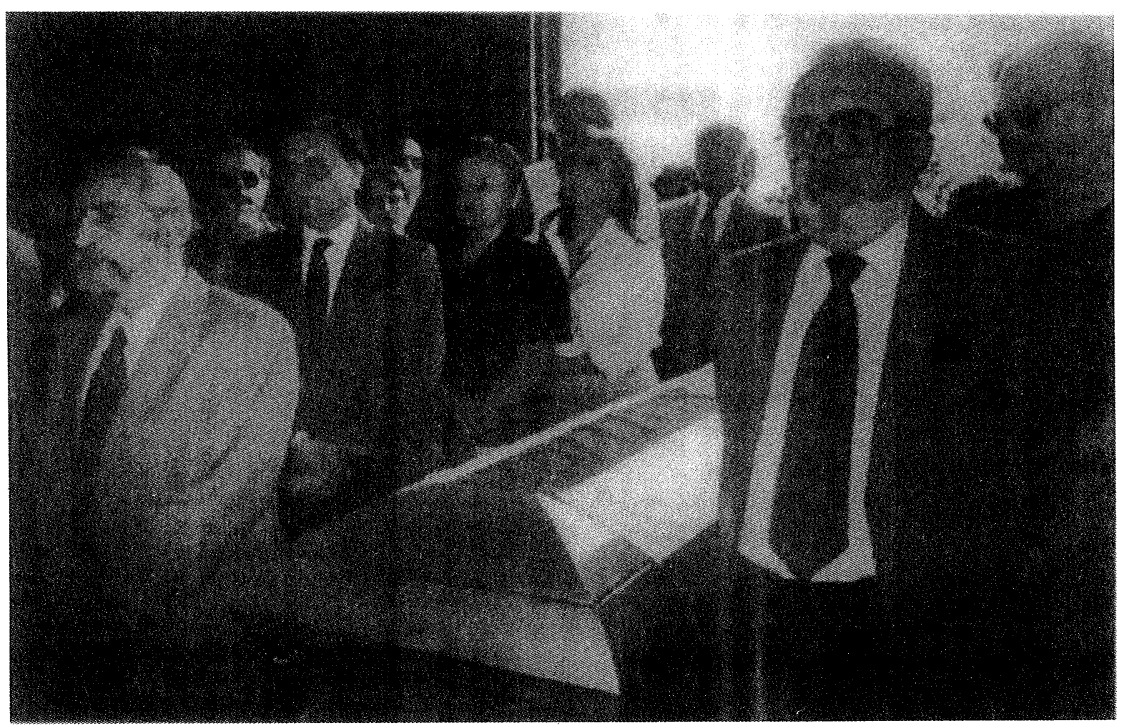

${ }^{1}$ Acto académico in corpore presente, Universidad de Puerto Rico, 12 de diciembre de 1996. Fotografía de Ricardo Alcaraz, Diálogo 10 (enero 1997) 95: 19. 
pose, la tensa mueca de Rosario denota algo más que pésame, una inquietudo incomodidad que alguien podría confundir con la culpa. El cabello echado atrás, Mayra relaja el cuerpo un poco para repartir mejor el peso del dolor. Al fondo, el resplandor de la intemperie dibuja una aureola sobrenatural sobre los hombros de Wico, pero el rostro oscurecido parece arrugarse, preocupado por el reto de la sucesión. A la izquierda, caras ponderadas se desvanecen en las sombras; es alli donde imagino ocultos los bigotes de Luis Nieves. Sólo la desatención de Edgardo, calva despeinada, media sonrisa guasona, desentona con la formalidad luctuosa del retrato. Trae camisa de poloy, tras gafas oscuras ray ban, mira de reojo el féretro como queriendo susurrarle al finado noticias frivolas sobre el último partido de béisbol. Toda la fotografia hace una sola pregunta:

¿Cuánto de la visión muere con el visionario?

\section{El ENTIERRo DE GoNZÁLEZ}

La pregunta que quiero hacer a continuación es ¿cómo la ficción puertorriqueña de los ochenta responde al emplotment ${ }^{2}$ que hace José Luis González de 1898 según el metarrelato nacional propuesto en obras como "El país de cuatro pisos" (1979), La llegada (1980) y Nueva visita al cuarto piso (1986)? ¿Qué huella dejan sus postulaciones en el imaginario literario? La reinterpretación del 98 planteada por González concurre con un reordenamiento del archivo insular y una renovación en los métodos historiográficos y sociológicos que se dan en la isla a partir de los setenta con la llamada "nueva historia". Tal renovación apoyó lateralmente los cuestionamientos de la versión oficial que González hizo desde su exilio mexicano. ${ }^{3}$ Como han señalado ya varios críticos, se dio en esta coyuntura un resurgimiento del tema histórico en la ficción de Luis López Nieves, Rosario Ferré, Edgardo Rodríguez Juliá y otros escritores de la llamada generación del setenta. Tal revisionismo tenía que confrontar la tradición literaria isleña que quiso contradecir la proclamación metropolitana de la guerra del 98 como "splendid little war" o romántico "paseo triunfal" representando la invasión norteamericana como pesadilla reiteradora del miedo a que "nos coja el

\footnotetext{
${ }^{2}$ Adapto en este trabajo algo de la terminología que Hayden White despliega en los ensayos incluídos en Tropics of Discourse y The Content of Form. Inspirado por los arquetipos narrativos de la anatomía discursiva de Northrop Frye, White elabora en sus libros una taxonomía neokantiana del discurso historiográfico en la que plantea una correspondencia categórica entre el tipo de interpretación que hace el historiador de los datos (idiográfica, contextualista, organicista o mecanicista), su marco ideológico (anárquico, conservador, radical o liberal) y el emplotment o módulo narrativo dominante que escoge para narrar su versión de la historia (romance, comedia, tragedia o sátira). Aunque discrepo del ordenamiento que hace White de sus categorías (no coincido, por ejemplo, en que la narración cómica implique por necesidad un concepto conservador), incorporo en este trabajo el principio de que el relato nacional adopta diferentes entramados genéricos de acuerdo a interpretaciones ideológicas dispares de la invasión del 98 . En el caso de la ficción ochentista, el 98 como comedia representa una postura progresista-radical (González), como tragedia/épica representa una postura nacionalista-conservadora (López Nieves), como romance una postura progresista-anexionista (Ferré) y como sátira una postura anárquico-carnavalesca (Rodríguez Juliá).

${ }^{3}$ Sobre la curiosa simbiosis entre el revisionismo en el campo socio-historiográfico y las innovaciones en la creación literaria durante esta época, véase a Díaz Quiñones ("Recordando el futuro imaginario") y García Calderón.
} 
holandés" (según el Antonio S. Pedreira de Insularismo), como traumático desengaño de las aspiraciones liberales (según el Manuel Zeno Gandía de Redentores), o como profanación bárbara que había que purificar con la conflagración (según el René Marqués de Los soles truncos). La versión alternativa configurada por González ("no nos ha cogido el americano") solicitó del imaginario literario una nueva visita al momento de la ocupación militar para resolver si el recuerdo de la llegada como violación territorial era, en resumen, una fantasía insolvente.

Sin embargo, ninguna de las ficcionalizaciones del 98 que dialogan con la polémica reinvención de González resulta ser una confirmación incondicional de su metarrelato. Tampoco son refutaciones absolutas ya que tienden a adoptar dos de sus conceptos históricos fundamentales: 1. la noción agonista de un país bifurcado en proyectos nacionales irreconciliables; 2 . el reconocimento de una estratificación socio-étnica y cultural de díficil armonización. A fin de cuentas, ninguna comparte la confianza que manifestó González en la supervivencia asegurada de la nación mulata-popular como estado independiente y descolonizado. A través de los ochenta, vemos en la ficción puertorriqueña una desintegración de la teleología de González en la que se pierde el optimismo afirmativo, la certidumbre documental y la transparencia histórica. O se regresa a una visión catastrófica y conspirativa, o la noción del romance triunfal adquiere credenciales literarias, o se articula una versión carnavalizada y antitélica para enterrar no sólo la profecía emancipatoria de González sino tambien sus estrategias ilustrativas y sus métodos narrativos. En las con(tra)figuraciones del 98 que hace la narrativa ochentista ("Seva" de Luis López Nieves, Maldito amor de Rosario Ferré, y El cruce de la Bahía de Guánica de Edgardo Rodríguez Juliá) vemos tanto la influencia controvertida de las teorías gonzalianas como el sepelio de González como visionario-narrador.

\section{El país de UN SOlo piso}

La obra que González escribió a partir de los setenta instó en la escritura ochentista una reconsideración de las nociones históricas que presumían un antagonismo irrevocable entre las intenciones del imperialismo norteamericano en la isla y el desarrollo emergente de la nación. Tanto en la ensayística en torno a la ontología cultural de la generación del treinta como en el discurso ultranacionalista y contestatario de Pedro Albizu Campos se consideró que el cambio hegemónico signado en 1898 surtía un efecto retardador - a lo más, traumático; a lo menos, desorientador-en el proceso nacional. Albizu y sus seguidores interpretaron la ocupación norteamericana como una catástrofe que amenazaba con ultimar la nación justo en la última etapa de su devenir como cuerpo político-cultural. La crítica más reciente ha reconocido que en el discurso treintista de Pedreira no se representó la invasión como un evento fundamentalmente corrosivo o traumático sino como una desviación que detenía el desarrollo de lo que Pedreira discretamente llamó la "personalidad" (nunca la "nación") puertorriqueña, al desbaratarse el proyecto autonómico. Tras balancear y calibrar los adelantos en el orden material contra los retrasos en el espiritual, los escritores del treinta concluyeron que las primeras tres décadas de coloniaje bajo los Estados Unidos habían sumido al país en un estado de suspensión o transición que bien podría superarse a través 
de la gestión minorista, magisterial y administrativa del grupo letrado hispano-criollo en colaboración efectiva con los sectores progresistas metropolitanos. ${ }^{4}$

Sin embargo, en "El país de cuatro pisos"(1980), González reinterpretó sorpresivamente la invasión americana no como un congelamiento transitorio y potencialmente superable (versión treintista) o una catástrofe que había que reprobar con la militancia armada(versión nacionalista) sino como una facilitación irónica del proceso nacional. Tomando como modelo el formato ensayístico usado por Roberto Fernández Retamar en Calibán (donde el intelectual tercermundista responde a una pregunta cargada poniendo al descubierto los presupuestos allí encerrados para entonces anularlos), ${ }^{5}$ González ofrece a la interrogante capciosa de "cómo ha sido afectada la cultura puertorriqueña por la intervención colonialista norteamericana" una respuesta inusitada y reafirmadora. Según González, la cultura puertorriqueña auténtica contaba en 1980 con una mayor efervescencia y solidez histórica gracias a (y no a pesar de) la situación colonial que surgió con la Guerra Hispanoamericana.

La pluralización marxista-gramsciana del concepto de nación que introdujo González con su metáfora de los "cuatro pisos" de un país-edificio a medio hacer situó la sede de la personalidad nacional en los cimientos inamovibles de la construcción: el primer piso afroantillano de carácter popular integrado por esclavos, cimarrones, libertos y campesinos pobres a través de los primeros tres siglos de dominación española, que logra su plasmación cultural a espaldas del oficialismo borbónico en el siglo dieciocho. ${ }^{6}$ Sobre este piso diversas

${ }^{4} \mathrm{Ha}$ sido un error asumir que, en su crítica al "independentismo tradicional puertorriqueño" (El país 38), González equiparó el nacionalismo militante de Albizu Campos con el culturalismo de Pedreira. No creo que González hubiera asumido que la interpretación del 98 hecha por la generación del treinta fuera tan "traumática" como la albizuísta. Recientemente, Arcadio Díaz Quiñones ha comenzado a deslindar estas visiones, distinguiendo una postura intransigente de "guerra santa" en el hispanismo católico-militante del albizuísmo, de otra menos recalcitrante y más receptiva al aporte norteamericano en el hispanismo secular de los escritores treintistas. Opino que estos deslindes aparecen ya esbozados en la ensayística de González. (Percibimos, de hecho, en los últimos trabajos de Díaz Quiñones una suavización de la crítica dura que formuló al imputar un mito bíblico de caída y redención al hispanismo de Pedreira y Tomás Blanco en su artículo "Escribiendo el futuro imaginario" cuando circunscribe tal mito al marco nacionalista, desligándolo del discurso treintista, en su reciente ensayo "Isla de Quimeras".) De igual forma, la caracterización del cambio hegemónico como "catástrofe pauperizante" en la obra cimera de Tomás Blanco - Prontuario histórico de Puerto Rico - no puede traducirse a un condena absoluta del régimen americano al modo albizuísta ya que el libro concluye con una propuesta de commonwealth siguiendo el modelo territorial del Reino Unido.

${ }^{5}$ Retamar escribe los "apuntes" de Calibán a partir del desmantelamiento analítico de una pregunta (“¿existe una cultura latinoamericana?") que le hace un periodista europeo en una entrevista. González organiza las "notas" de su ensayo en forma análoga deconstruyendo la pregunta que le hacen "un grupo de jóvenes estudiosos puertorriqueños".

"Tanto como los de una casa, estos "pisos" - por su carácter cronológico de historicidades extendidas y sedimentadas por largos procesos de inmigración y colonización - evocan también la dinámica de capas geológicas reunidas en densas estratificaciones transversales. Creo que hay algo del longue durée braudeliano en el concepto del primer piso mulato de González ya que la conformación ideoeconómica de su mentalidad cotidiana y su etnicidad ocurre con una lentitud geológica de varios siglos, lo cual le da un poder de permanencia que no tienen las inmigraciones oficiales o intervenciones geopolíticas de la "historia inmediata", por fuerza más efímera. De seguro influyó también, en la dimensión etnográfica de este concepto ultra-heterogéneo del país, la representación de Puerto Rico 
contingencias de la historia imperialista echarían encima nuevos estratos sociohegemónicos—el segundo piso criollo-propietario constituido por inmigrantes europeos a partir de la Real Cédula de Gracias de 1815; el tercer piso del régimen colonial norteamericano como consecuencia de la Guerra Hispanoamericana; el cuarto piso del desarrollismo muñocista a partir de la década de 1940 como respuesta a la crisis del coloniaje tutelar. ${ }^{7} \mathrm{Se}$ reconfigura con cada "piso" la lucha de clases; sin embargo, en la dinámica histórica resultante, los pisos superiores se desmantelaban entre sí sin afectar señaladamente el desenvolvimiento autocontenido del primer piso mulato-popular. A pesar de sus evidentísimos propósitos expansionistas y asimiladores, de acuerdo a González el cambio hegemónico de 1898 no logró descarrilar la teleología nacional del sector popular-mulato ya que optó por enconar su efectos nocivos en la ideología cultural y el poder económico de los hacendados decimonónicos que mantenían a tal sector bajo su opresión. Los designios desarticuladores del imperialismo norteamericano (Ley Foraker, Ley Jones) se asestaron sobre los mecanismos de control económico y legislativo de esta clase dirigente, abriendo casi por azar, sin un real desideratum libertador, un mayor campo de acción política y cultural para los grupos reprimidos del primer piso (el movimiento obrero; mayor presencia y afirmación étnica en los deportes y las artes) y algunos silenciados dentro del segundo (el sufragio y la profesionalización femenina). La visión geopolítica de González proponía entonces un cuadro paradójico de contradicciones sociales: sectores que podrían seguir silenciados en los espacios internos de la metrópolis (la clase obrera, los negros, las mujeres) cobraban extrañamente mayor desenvoltura y visibilidad en la dinámica del territorio al reducirse la prepotencia del prócer criollo. ${ }^{8} \mathrm{Al}$ contradecir la visión de 1898 como catástrofe o retraso histórico, González no pretendía argumentar que la nueva colonización de la isla no había surtido efectos perniciosos, sino que tales efectos estuvieron

como un compendio inarmónico de subculturas que propusieron los antropólogos de orientación marxista en el libro The Peoples of Puerto Rico. Otra novela de González, Balada de otro tiempo (1978), reproduce fielmente los contrastes y desfases del mapa socio-regional ("cane subcultures", "coffee subcultures", "urban subcultures") que configuraron los capítulos de este importante proyecto de la Universidad de Columbia en el que colaboraron Julian H. Steward, Eric Wolf y Sidney Mintz.

7 "The period from 1936 to 1940 was one of the most critical in Puerto Rican history[...] It was a crisis of the whole system of tutelage" (Morales Carrión 236). Podríamos considerar que lo que Morales Carrión y otros investigadores llamaron la era del tutelaje (1898-1948) es lo que González estima como "tercer piso". Aunque con sus dos primeros "pisos" González parece fundir en un concepto sincrónico/socio-etnográfico/paradigmático/vertical las categorías de clase social, región geográfica y etnicidad, la entelequia gonzaliana de cuatro pisos sucesivos ilustra a la vez un concepto diacrónico/ histórico/ sintagmático/horizontal de las "cuatro grandes etapas históricas en la evolución de la sociedad puertorriqueña", según consigna en su charla de Stanford, "Una nueva mirada a un nuevo país" (61).

${ }^{8}$ González nunca argumentó que se diera menos racismo en la metrópoli que en la colonia. Su crítica a Tomás Blanco no contradice la severidad con que el último caracterizó el prejuicio racial en EE.UU. sino la pretención de alegar la ausencia del tal prejuicio en Puerto Rico a través de un contraste maniqueo entre continente e isla. González siempre manifestó una creencia en la naturaleza eminentemente racista de la cultura norteamericana (véase, para citar uno de muchos ejemplos, "Puerto Rico en la Hora Cero" 31), pero estuvo atento al resultado cómicamente emancipador de la política americana en las relaciones étnicas insulares. 
circunscritos al proyecto patriarco-señorial de nación de lo que famosamente llamó el "segundo piso" de la sociohistoria puertorriqueña, un proyecto que nunca fue real.

Según González, el primer piso-nación popular no sería afectado adversamente sino beneficiado por los desajustes que sufriría el segundo al agudizarse la crisis hegemónica de la clase propietaria criolla. Antagonizando a muchos críticos marxistas, González nunca consideró que la intervención colonial americana hubiera desatado una asimilación servil en el primer piso. Siguiendo a Hostos, González no interpretó la "americanización" de Puerto Rico como un fenómeno desculturador que imponía sobre las masas populares valores y expresiones fóraneas y enajenantes, sino como un proceso de modernización que, al trasladar a Puerto Rico a un orden económico industrial, aceleraba la formación de un proletariado urbano mientras descomponía el orden agrario-patriarcal. ${ }^{9}$ Por otra parte, las contradicciones generadas a partir de los 40 por el desarrollismo dependiente del cuarto piso (el Estado Libre Asociado actual) hacían imposible la anexión formal del territorio al éste constituirse finalmente en un pérdida de riqueza para la metrópoli a través de desembolsos federales que le daban una mayor e inquietante fuerza y presencia a la alteridad de la nación mulata dentro del país. González no dudó entonces de la independencia como desenlace: después de que el tercer piso neutralizara al segundo, el cuarto y el tercero se cancelarían entre sí. ${ }^{10}$ González articuló también, a partir de su lectura de La Guaracha del Macho Camacho y su apreciación de la pintura de José Rosa, una teoría sobre cómo el fenómeno de la plebeyización desbastaría la insulación cultural hispanófila y elitista del segundo piso en la medida que, al ser desplazados y desclasados por los aparatos hegemónicos y tipológicos norteamericanos, los burgueses criollos no podrían evitar ceder a modelos de comportamiento impuestos de abajo hacia arriba y ser recategorizados y absorbidostransculturados, plebeyizados, africanizados en las costumbres si no en la sangre-dentro del primer piso. " Es decir, los ladrillos desprendidos en el desbarajuste de las plantas altas servían para reforzar la paredes de la planta baja.

\footnotetext{
${ }^{9}$ Sobre la interpretación hostosiana de la americanización como modelo transferible de la modernidad, según González, véase "Una nueva mirada [...]" (65) y la introduccíon a la antología de Hostos que preparó González justo después de publicar El país (Textos 6). Manuel Maldonado Denis formuló mejor su desacuerdo con la visión modernizadora y mayormente benigna que tuvo González de la americanización en cuanto al desarrollo y la radicalización de la clase obrera en su reseña "En torno a 'El país de cuatro pisos' [...]" (154-5).

${ }^{10}$ Esta tesis, algo esquemática en El país (40-2), se esboza con más detalle en "Puerto Rico en la hora cero", donde González expone cómo la crisis estructural del ELA no podrá resolverse con la alternativa anexionista no sólo porque ésta (ya había solo descartada como opción) durante el tercer piso sino porque la economía artificial de la isla no la hacía compatible con la exigencias metropolitanas de productividad. González concluye: "La fuerza del independentismo puertorriqueño es, pues, la única que a fin de cuentas está llamada a prevalecer: la fueza de la necesidad histórica" (31).

11 "La masa popular puertorriqueña, huérfana en grado mayor de la 'ejemplaridad' de una clase dirigente capaz de ofrecerle modelos válidos de creación artística [...] empezó hace varios lustros a vivir por sí y desde sí, a nutrirse de su propio jugo e inspiración plebeyos. Plebeyismo es creación de modelos desde abajo y su imposición hacia arriba" ("Plebeyismo ..." 99). Ambos Rosa y Sánchez muestran en su obra signos de "estilo vital plebeyo capaz de penetrar y conquistar los dominios de la expresión estética superior" (101).
} 
Esta dialéctica (y no el voluntarismo de la lucha armada ni el liberalismo del proceso electoral) era lo que garantizaba para González el camino irreversible a una independencia de base popular con una identidad caribeña. La misma representaba una restitución del proceso nacional asumido por el primer piso en el siglo dieciocho, proceso que González nunca pone en cuestión. A lo más, la dinámica de los pisos superiores podría afectar el ritmo del desarrollo del primer piso como nación—en el siglo diecinueve fue interrumpido; en la primera mitad del veinte tomó nuevos bríos; en la segunda se aceleró exponencialmentepero no lo atrofiaba ni lo desorientaba. La fragilidad radicaba arriba: no en la "muchedumbre" de la que se lamentaba Rosendo Matienzo Cintrón sino en la clase letrada representada por Pedreira; no en el "pueblo dormido" que tanto desesperó a Albizu Campos sino en la "legión de propietarios" del discurso nacionalista conservador; no en las hordas sugestionadas por los ideales del American Dream sino en las contradicciones estructurales del capitalismo imperial norteamericano. He aquí por qué el proyecto literario que Gonzalez dejó sin terminar al morir fue una biografía novelizada del Miguel Henríquez. ${ }^{12}$ Con esta obra de culminación, González visualizaba otorgar, a través del relato del zapatero mulato vuelto corsario que prospera en el territorio subalterno al aprovechar la crisis coyuntural de las hegemonías imperiales, un mito fundacional de los orígenes remotos de la nación socialista y mulata cuya consolidación González creía ver acercándose, país ya de un solo piṣo.

\section{La LLEGADA: Despedida A los IMPerios}

En El pais de cuatro pisos, Nueva visita al cuarto piso y otros ensayos sueltos publicados en revistas mexicanas y norteamericanas, González hizo su elaboración teórica de un argumento que reemplazaba el metarrelato albizuísta anti-yanqui - que prescribía la resistencia y el martirio como medidas para preservar la patria asediada - por un relato gradualista de irrevocable emancipación. Estos planteamientos ensayísticos fueron acompañados por un cuadro imaginario que sirvió para ilustrar el nuevo emplotment. La novela La llegada se ubica en el instante preciso en que comienza a echarse el tercer piso de la hegemonía norteamericana sobre la conflictiva construcción proto-nacional de los primeros dos: el último día de la Guerra Hispanoamericana. Más que resemantizar, cual desmentimiento freudiano de una fantasía de hostigación, el 1898 como invasión traumática y forzosa del territorio, el título recalca la condición de espera, ansiosa u optimista, en la que se encuentra el cuadro sinecdótico-transversal de la pirámide social del pueblo de Llano Verde la noche antes del arribo de las tropas norteamericanas. ${ }^{13}$ A través de un

\footnotetext{
12 "Mi profundo interés por la personalidad y la ejecutoria de Miguel Henríquez nace de que veo en él a uno de los representantes más vigorosos —el más vigoroso sin duda junto a José Campeche— del 'primer piso' popular y mestizo en que tuvo su domicilio inicial la nacionalidad puertorriqueña [...]" (Nueva visita 40). En las páginas que siguen, González narra su esfuerzo infructuoso de compilar una documentación veraz sobre la vida de Henríquez.

${ }^{13}$ Sostengo aquí (y a través de mi ensayo) un diálogo crítico con los importantes planteamientos que hace Guillermo Irizarry en el estudio de La llegada incluído en este número de la Revista Iberoamericana, al cual refiero al lector para una sinopsis detenida de la novela. Los penetrantes argumentos de Carlos Gil en su libro El orden del tiempo sobre cómo el discurso histórico-mítico puertorriqueño remite insistentemente a la metáfora de la espera son aplicables al cuadro situaciónal
} 
multiperspectivismo construído con las técnicas narrativas de la interioridad más avanzadas, los diferentes integrantes del edificio colonial escenifican durante esta espera una comedia de reposicionamiento oportunista para recibir a los nuevos amos. ${ }^{14}$ Las rameras del pueblo, los burgueses autonomistas y (de manera más oblicua) el carpintero sindicalista traman en esta víspera diversos ardides para asumir la ubicación más favorable ante la mirada del invasor/redentor, confiados en el avance potencial que les propendrá la reconfiguración del orden económico-social con el cambio hegemónico. Mientras, los miembros de la oficialidad española huyen de la confrontación vaciando los signos de su poder (la guarnición retrocede en desbandada, el sacerdote desgraciado se resguarda y cierra la iglesia, el soldado herido asume otra identidad y entierra su uniforme) o tomando precauciones contra el revanchismo insular (el alcalde sale a consultar a sus informantes).

La comicidad de esta configuración se desprende de la ironía prospectiva que el conocimiento histórico del lector avisado reconocerá en las falsas expectativas o temores de los que esperan. Esta lectura prevee ya: 1. la muerte anunciada de las esperanzas de anexión, democratización, federación y prosperidad inmediata que el líder autonomista Juan José Benítez le comunica a su titubeante esposa; 2. el fiasco que significará la Coalición socialista-republicana de 1924 para el adelanto consecuente del movimiento obrero con el que sueña el sindicalista Catalino Romero mientras espera la llegada de Santiago Iglesias con las tropas; 3. la absurdidad de la desbordada visión demonizadora que tiene el cura de los invasores; 4. la equivocación de Adrián Colomer al temer que con la ocupación se acabará la ambición separatista, etc. Los desencuentros y fricciones entre las perpectivas contenidas en la diégesis de la novela incrementan a su vez este efecto irónico, sobre todo la gran disonancia entre la visión de los norteamericanos como agentes ilustrados

de La llegada (27-147). Por otra parte, hay que señalar que al representar a agosto de 1898 como un momento de receptiva y casi unánime simpatía hacia los norteamericanos, González no antagoniza el consenso historiográfico. Tanto las versiones "clásicas" del 98 (Rivero, Brau, Friedel, Harding Davis, Beisner, Sandburg, Pedreira, Blanco, Morales Carrión, Maldonado Denis y Rosario Natal) como las revisionistas (Picó y Gervacio García) pintan no una "invasión" sino una "llegada" en donde se recibe pacífica y hasta festivamente a las tropas extranjeras. Así lo señalan los epítetos que escogen para adjetivar la ocupación: "un paseo triunfal", "luna de miel", "apoteosis del invasor" (Rosario Natal), "éxito fulminante" (Picó), "féte de fleur" (Harding), "splendid little war" (Friedel). Es más, a partir de 1900, como bien señala María Dolores Luque de Sánchez en su imprescindible estudio, cuando, "tras la euforia de los primeros meses" (192), la ley Foraker ocasiona en el patriciado criollo un profundo y lacerante desengaño al establecer un restringido régimen tutorial que frustra severamente el ideario democrático/anexionista/autonomista y la expectativa por la otorgación del "status" jurídico de "self-government" que la Unión americana había concedido a otros territorios (Nuevo México, Hawaii, Alaska) como vía de incorporación al sistema federal. La originalidad de González radica en emblematizar este momento - y no 1900 - para denunciar la omisión tan frecuente en la historiografia de afirmación nacional de toda referencia a los profundos intereses anexionistas que albergaba todo el autonomismo y mucho del separatismo finisecular. González quizo así recalcar el carácter reaccionario, inorgánico, conservador y resentido de mucho del independentismo hispanicista del pos-noventaiocho (El país 30-8).

${ }^{14} \mathrm{~A}$ pesar de la novedosa factura narrativa, el énfasis a través de la novela en los acentos y expresiones regionales, en los cuadros dialogados y, sobre todo, en la descripción trabajada de la indumentaria sugiere que la comedia teatral de costumbres opera como un modelo latente dentro del texto. 
del progreso social y material que albergan los isleños y los arraigados prejuicios y rencores develados en el monólogo interior indirecto de la única subjetividad invasora incluída en la novela: la del Coronel Mackintosh, cabeza del regimiento. Cada elemento en la caracterización de este monólogo está coordinado para contradecir las ilusiones y aprensiones respecto al mito de la "superioridad anglosajona" desarrolladas en las focalizaciones previas. La prepotencia industrial y táctica que Benítez y la Niña Engracia le atribuyen al "genio norteamericano" se desmorona ante la diatriba mental que lanza Mackintoch contra la planificación ineficiente y desastrosa de la campaña (la distribución de rifles de pólvora obsoletos y uniformes de invierno para una campaña estival anegada por las lluvias, las provisiones enlatadas de carne descompuesta, los torpes voluntarios de marcha desigual e indisciplinada). Las esperanzas que ponen Benítez y Martínez Coss en la incorporación igualitaria del territorio dentro de una "república de repúblicas" que tolere idiosincracias y lenguajes regionales quedan ironizadas cuando, a través de la focalización interior, el narrador hace transparentes tanto los designios imperiales y racistas de Mackintosh hacia el país como su cínica deducción de que la política norteamericana está regida no por el mandato popular sino por favores clientelistas y la fácil manipulación de la opinón pública bajo intereses corporativos como los de Randolph Hearst. Esta cómica deflación de la Guerra Hispanomericana como misión civilizadora se agudiza al destacarse la atribulada condición física del coronel durante la avanzada a Llano Verde: la rigidez y compunción que la Niña Engracia y el alcalde interpretan erróneamente como signos de un ejemplar comportamiento marcial son ocasionados por los achaques diarreicos que la disentería ha impuesto sobre el cuerpo invasor, desacostumbrado a los rigores del trópico (y que fue origen del mayor índice de bajas en esta "campaña admirable"). ${ }^{15}$ A modo de anticlímax, la "llegada" del discurso focalizado del Mackintosh cascarrabias en los últimos capítulos pronostica el gran mentís que el siglo veinte le hace tanto a los ideales anexionistas del segundo piso como a la recepción dada a los americanos como "redentores" por los puertorriqueños.

Con esta simulación ficticia de una mentalidad colonizadora que deslee con ineptitud la realidad territorial (y es a su vez desleída por ella), González hace de Mackintosh una alegoría precursora de los gobernadores y oficiales insulares que vendrán con el nuevo régimen tutorial: su incapacidad para ajustarse psico-climáticamente a esta "réplica insular del Purgatorio" (98), su paranoica suspicacia contra los "campesinos aprovechados" que suben "el precio de oro" a los extranjeros (100) y su escepticismo hacia las capacidades del país racial y sanitariamente "infecto" para autogobernarse (100-1) se perfilan más de acuerdo a las condescendencias y frustraciones destiladas en los informes de los futuros officers del territorio que a cualquier documentación oriunda del 98. La expresión que usa MacIntosh para traducir a Llano Verde - “Green Hell" (102-3)- sirve de premonición de

\footnotetext{
${ }^{15}$ Sorprenden, incidentalmente, los paralelos entre la llegada de Mackintosh a Llano Verde que inventa González y la entrada del general Roy Stone en Utuado que Fernando Picó historia en su libro La guerra después de la guerra (73-5). En el capítulo dedicado a la invasión, Picó documenta mucha de la desmitificación lograda por el cuadro ficcionalizado de la novela: la calidad novicia de las tropas, la desorganización de los servicios de salud y alimentación, las lluvias y las bajas ocasionadas por la tifoidea y la disentería.
} 
lo que será la crisis del tutelaje que pondrá fin al período histórico del tercer piso tras la violencia que surge en el país a partir de los desajustes de la depresión, el asesinato del Coronel Riggs, las movilizaciones nacionalistas y la desorientación partidista entre 1935 y $1940{ }^{16}$ Esta profecía terminal del tercer piso que Mackintosh encarna se vuelve más explicíta en la ironización de su entrada "triunfal" al diferenciado espacio socio-simbólico de Llano Verde. Las tropas avanzan primero a través de "construcciones modestas, casi todas de un solo piso y de madera" (121, énfasis mío) ubicadas en la barriada mulatapopular-obrera del pueblo, antes de llegar a la plaza del centro, sede del poder económico y administrativo de los hacendados y comerciantes y que se caracteriza arquitectónicamente por "varias casas de dos pisos con balcones en el superior" (129, énfasis mío). Al desplegarse oportunamente durante la marcha la bandera americana en uno de los balcones de la zona de dos pisos, ocurre un aplauso atronador que desenmascara los intereses anexionistas de este sector social; por otra parte, al cruzar por la periferia urbana de un solo piso, Mackintosh no puede advertir en el indescifrable público mulato y paupérrimo "ni hostilidad ni simpatía" (129). Es en esta zona plebeya donde Mackintosh confronta un anticipo del futuro de la tutoría norteamericana en el país, de sus "días contados": el paso de la carreta funeraria con el féretro rústico del informante difunto obliga a la tropa a detenerse. Este "tétrico y casi fantasmal" entierro de pobres (126) simboliza no sólo el fin actual del regimen español y sus secuaces sino también el sepelio futuro de la hegemonía americana. "Holy Jesus, what an omen!" exclama "sin aliento" Mackintosh (126) al reconocer una confirmación fugaz de la suerte "corruptora" que sufren, según sus presentimientos, los extranjeros en tal territorio (“¿no habría de sucederles lo mismo a ellos por meterse en estos andurriales?" 101), tal como el lector avisado debe ver también allí el cádaver de fracasado coloniaje norteamericano a venir, destronado por el avance nacional del primer piso mulato. A esta clase pertenecen los que conducen el funeral, los viejos exesclavos Quintín y Petronila, personajes nunca ironizados por el narrador cuyos rostros indiferentes son los primeros en confrontar la mirada invasora; dentro de la simbología ucrónica de la novela, al ser "verdaderos puertorriqueños" por no responder a lealtades foráneas (incluyendo lazos filio-sentimentales con África), Quintín y Petronila están encargándose de enterrar prematuramente al resto de los pisos en este funeral para así "heredar" el país descolonizado. De esta forma, el uso paratextual en la novela de ilustraciones tomadas del archivo fotográfico de la infantería norteamericana y la emblemática triunfalista del águila no sirve para confirmar el carácter documentado del relato (según arguye Daroqui 108-113) sino para acentuar la vacuidad de estas imágenes y su irrelevancia final. La ironía del relato nos informa que los vistosos uniformes que se destacan en las fotos son/serán tan falsos y obsoletos como el que entierra el raso Fermín en el patio del ayuntamiento.

16 “Green Hell” recuerda la expresión sensacionalista que sirvió de título a la crónica novelada del norteamericano Wenzell Brown sobre sus años como maestro en el sistema insular de educación pública durante la depresión. Dynamite on our Doorstep. Puerto Rican Paradox es uno de los testimonios más dramáticos de la crisis del modelo tutelar colonial en la década del treinta. 


\section{3. "Seva" o la Épica Paranoica}

Si González representa la invasión como una comedia para alegorizar el saldo final de los sistemas imperiales en Puerto Rico, en el cuento "Seva" Luis López Nieves narra una empresa épica/trágica de hallazgo y desocultamiento de una intervención militar secreta "anterior" a la que González ficcionaliza. Desplegando una estrategia narrativa muy contraria a la de La llegada que se manifiesta como una ordenación coherente de documentos falsificados (13), el relato empieza con una nota del propio Nieves dirigida al director de un semanario independentista garantizando la autenticidad de un porfolio de documentos inéditos y correspondencia confidencial que ha recibido de su amigo, el historiador Víctor Cabañas. Esta carta introductoria también implica que la reciente desaparición de Cabañas es el "precio muy alto" que ha pagado por probar que un primer intento de invasión naval iniciado por los norteamericanos el 5 de mayo ${ }^{17}$ en en la costa oriental fue bochornosamente derrotado por la heroica resistencia de los puertorriqueños del pueblo de Seva (de 721 habitantes) tras cuatro semanas de lucha frontal y un saldo de dos mil bajas para los invasores. A través de la presentación secuencial de textualidades simuladas, el cuento narra cómo, con la colaboración de autonomistas y anexionistas destacados, el Comandante Nelson S. Miles organizó la invasión del 25 de julio (la que anota la historia) para tomar al pueblo de Seva por sorpresa, erradicarlo en una masacre según el procedimiento genocida aplicado a las poblaciones indígenas en la expansiones fronterizas continentales, construir sobre sus ruinas el pueblo de Ceiba y una base naval para despistar a los investigadores, y modificar sistemáticamente los archivos oficiales para borrar toda evidencia cartográfica o documental de su existencia. Tal estratagema imperial sirve no sólo como desquite supremacista sino también para substraer el ánimo nacionalista que el recuerdo de la victoria pírrica de Seva podría inspirar en el territorio. Las cartas de Cabañas reproducidas por Nieves narran a su vez una obsesiva búsqueda internacional por indicios de la Seva "desaparecida" en Washington, Galicia y otros centro metropolitanos. De esta forma, Cabañas rescata y envía a Nieves materiales que se corroboran mutuamente según las exigencias de la historiografía "ciéntifica": 1. Páginas robadas del diario privado de Miles sobre la invasión que detallan el humillante fracaso de su flota y las terribles represalias contra Seva; 2 . Un mapa decimonónico "inalterado" de Puerto Rico donde figura el pueblo; 3. Un affidavit que certifica la veracidad de un largo testimonio del recluso Ignacio Martínez, negro de 95 años y único sobreviviente de la masacre, que Cabañas consigue grabar en la sierra oriental de la isla. El historiador figura así como juglar de las hazañas de los intransigentes de Seva y buscador tenaz de sus restos archivísticos y arqueológicos. $^{18}$ Tanto el hallazgo como el esfuerzo de Cabañas "revelan" que la versión de la Guerra Hispanoamericana como recibimiento festivo y dócil de los norteamericanos por los puertorriqueños es una fabricación, un engaño sugestionador.

\footnotetext{
${ }^{17}$ La selección de esta fecha no es arbitraria ya que evoca la conmemoración mexicana del rechazo de la tropas invasoras de Napoleón III en Puebla en 1862.

${ }^{18}$ El cuento termina con la idea melodramática de que Cabañas ha desaparecido tras declarar su intención de penetrar subrepticiamente en la notoria base naval Rooselvelt Roads para excavar por restos del pueblo y desenterrar la evidencia más inconstestable. De esta forma, se sugiere que Cabañas termina sufriendo el mismo fin que el de su objeto de investigación.
} 
No me interesa aquí reincidir en la apreciación del cuento como un acto ingenioso de simulacro o desinformación histórica para manipular la credulidad isleña o reactivar el orgullo patriótico ${ }^{19}$ sino ver cómo la recuperación del relato catastrófico del trauma que hace Nieves contradice calculadamente la reinterpretación del '98 de González. A pesar de alegar ser un texto concebido antes de La llegada cuya redacción final fue motivada por otras muestras de la nueva historiografía puertorriqueña, ${ }^{20}$ es claro que lo que Carlos $\mathrm{A}$. Pabón hatildado como la narración "neo-nacionalista" de "Seva" es una ansiosa contestación remitificadora al emplotment antiheroico que hace González del 98, un ejemplo de la categoría de tessera en las estrategias revisionistas que Harold Bloom ha llamado misreadings. ${ }^{21}$ La refundición que López Nieves hace de los ingredientes y motivos de $L a$ llegada evidencia un deseo de contra-entramamiento o reemplotment en donde los eventos del 98 dejan de ser una comedia perspectivista para tornarse en una épica inventada y despojada de la ironía que fundamenta la novela de González. La magnitud de la decepción que ocasionaron los documentos fabricados por Nieves radica en su capacidad de persuadir al lector a tomarlos absolutamente en serio.

Muchos personajes, motivos y símbolos de La llegada son transfigurados y resemantizados sistemáticamente en el relato de Nieves. El aquejado Mackintosh se transforma en el sangriento y revanchista Miles; el Benítez oportunista pero inconsecuente reencarna en un Muñoz Rivera colaboracionista y fraticida; Quintín, el "heredero" negro del país, se torna en Ignacio Martínez, el negro sobreviviente de la masacre. La espera ansiosa pero pacífica de Llano Verde se sustituye por el ataque sorpresa a Seva; el principio hermenéutico de la ironía prospectiva da paso al shock retrospectivo; las múltiples focalizaciones se traducen en panorama documental; el compilador de textos "verídicos" que pretende ser Nieves desplaza al narrador omnisciente de González. Más significativamente, la multiplicidad heteroglósica y discrepante del cuadro de voces sociales del cauteloso pueblo central de Llano Verde se torna en la homogeneidad silente y unánime que demuestra el heroico pueblo costero de Seva con su resistencia y sacrificio. En la versión contrafactual de López Nieves, el edificio nacional no tiene pisos y, por ende,

\footnotetext{
${ }^{19} \mathrm{Al}$ no aclararse en su primera publicación (Claridad, 23 de diciembre de 1983) que el "dossier" preparado por Nieves era un cuento de ficción, se dió, para citar a Carlos A. Pabón, "una verdadera conmoción entre numerosos intelectuales que lo tomaron como un descubrimiento de 'gran envergadura histórica"' (549). Se organizaron comisiones para ahondar en los hechos y exigir la investigación del paradero de Víctor Cabañas y aparecieron letreros en grafitti proclamando que "Seva vive" en las afueras de la Base Naval Rooselvelt Roads. Para más detalles, véase la "Crónica" (Josean Ramos, Seva 57-87). Concuerdo en mi análisis del texto con varias de las observaciones críticas de Pabón en su ensayo, al cual remito al lector.

${ }^{20}$ Nieves indica que le dio "forma final al libro" después de leer "el libro sobre las revueltas del esclavos en Puerto Rico" (Seva 84). Se refiere a Esclavos rebeldes por Guillermo Baralt (Río Piedras: Ediciones Huracán, 1982).

${ }_{21}$ "Tessera $[\ldots]$ is completion and antithesis [...]. A poet antithetically 'completes' his precursor by so reading the parent-poem as to retain its terms but to mean them in another sense, as though the precursor had failed to go far enough" (Bloom 14). Los documentos encontrados por Cabañas "completan" el cuadro histórico pintado por La llegada, desentrañando una significación siniestra más "profunda" que lo que González "logró alcanzar".
} 
no padece de contradicciones sociohistóricas verticales: la nivelación de Seva por el bombardeo americano simplemente confirma su consenso monoglósico y horizontal. Su final "entierro" lo sitúa en la zona transcendental y fantasmática de lo telúrico y lo utópico: el reemplazo de la entrada cómico-triunfal en Llano Verde con el asedio destructor de "Seva" permite a López Nieves borrar las discrepancias socio políticas y fricciones internas de la sociedad decimonónica que destaca González. Contrario a Quintín, la negritud de Ignacio Martínez no simboliza su pertenencia al sector subalterno del "primer piso"; sirve en cambio de metáfora para la marginación que ha sufrido un concepto heroico, estático, indistinto, militante y virilizado de la nación y la puertorriqueñidad. A pesar de haber representado una "broma pesada" para muchos lectores, la engañosa seriedad del texto de López Nieves apunta a un retroceso hacia posturas metahistóricas anteriores a la de José Luis González; en particular al mito nacionalista de la nación asediada. Sin embargo, Nieves le da un nuevo giro a la noción del 1898 como catástrofe ya que en "Seva" ésta resulta ser no sólo más sangrienta sino aún más insidiosa al ocultarse conspirativamente los estragos más profundos del trauma. ${ }^{22}$ Cabañas/Nieves aparece entonces como un historiador-terapeuta que recobra/induce a todo lugar la memoria reprimida/inventada de una violación brutal.

Esta estrategia también encierra una vertiente latentemente hispanófila que se identifica con la dimensión más conservadora de los metarrelatos de Albizu, Pedreira y Blanco. La propuesta épica del relato está inspirada, según avala el mismo López Nieves, por la lectura de "la deslumbrante y maravillosa épica española" (énfasis mio). ${ }^{23}$ Aunque Nieves menciona tangencialmente la Ilíada y la Revolución Cubana como modelos legendarios alternos (85), esta declarada admiración por la épica peninsular resulta reveladora por su sobrada especificidad, eco del hispanocentrismo de la generación treintista y del independentismo tradicional. Más aún, en lo que pueda tener de épico el relato, "Seva" incide en la "monoglosia" que M. M. Bakhtin reconoció en el género de la epopeya. ${ }^{24}$

${ }^{22}$ De esta forma, Nieves también logra expurgar el tema del consenso finisecular anexionista de su metarrelato nacional. El mayor manifestante del silenciamiento del fenómeno criollo-anexionista logrado a través del colapso del espacio histórico que media entre 1898 y 1900 fue Francisco Manrique Cabrera, cuya Historia de la literatura puertorriqueña es tal vez la proclamación más agresiva de la tesis del 98 como trauma (159-60).

${ }^{23}$ Josean Ramos escribe: "Fue en Nueva York, precisamente, donde nació Seva hace unos siete u ocho años. Durante una de sus largas noches de estudios doctorales Luis López Nieves sintió de pronto una gran tristeza. Llevaba varias semanas sumido en el estudio de 'la deslumbrante y maravillosa épica española' cuando de golpe comprendió cuál era la causa de su nostalgia: echaba de menos una epopeya puertorriqueña. Esta tristeza ya no lo abandonaría y, tal vez para deshacerse de ella, a los pocos meses tomó una seria determinación: ya que no existía (o no se conocía) una gloriosa y potente epopeya que 'me emocionara y llenara de orgullo', sólo quedaba una cosa por hacer: inventarla" (834).

${ }^{24}$ Véase, de Bakhtin, "Epic and Novel". La leyenda de Seva ejemplifica las tres características constitutivas de la épica según Bakhtin: "(1) a national epic past -in Goethe's and Schiller's terminology the 'absolute past' - serves as the subject of the epic; (2) national tradition (not personal experience and the free thought that grows out of it) serves as the source for the epic; (3) an absolute epic distance separates the epic world from contemporary reality, that is, from the time in which the singer (the author and his audience) lives" (17). De acuerdo a Bakhtin, estas características aíslan un mundo ideal, solemne y sacrosanto, cuyas fronteras se vendrían abajo con el tipo de parodia 
Gracias al orden estratégico con que se presentan en el cuento, la diversidad diaglósica de los documentos simulados no obstaculiza, más bien reconfirma, el unánime efecto mitificador, aséptico y anti-paródico ( $\mathrm{y}$, por ende según Bakhtin, anti-novelesco) que alcanzan la confirmación acumulativa del carácter indómito de los seveños/puertorriqueños y la desocultación de los crímenes del imperio. De que "Seva" logra, a pesar del multivocalismo de sus "fuentes", una unidimensionalidad épica lo confirma la absoluta ausencia de ironía en las décimas y aguinaldos que, adoptando el rol de bardo popular, compuso José Manuel Torres Santiago para cantar el heroísmo de Cabañas, Martínez y los seveños; Nieves los incluye como apéndices imprescindibles a su cuento (91-8) y los caracteriza como emanaciones orgánicas al relato (86). Por otra parte, el maniqueísmo de esta "monoglosia" también promueve la visión paranoica de la memoria-nación que se piensa intervenida y manipulada. Esta desconfianza en la posibilidad de un archivo imperial confiable se comunica y se plasma en la última oración: “¿Dónde está Víctor Cabañas?”, que bien podría traducirse como "¿dónde está nuestra historia secuestrada?” Tal paranoia se revalida con la desaparición en una zona militar que es un mito destacado en el imaginario de la suspicacia insular: Cabañas busca los restos de Seva en el mismo suelo donde muchos puertorriqueños asumen que yacen depósitos indeclarados de armas nucleares en el Caribe (Rodríguez Beruff 161). ${ }^{25}$

heteroglósica que introducen los géneros serio-cómicos conducentes a la aparición de la novela moderna. "It is precisely laughter that destroys the epic, and in general destroys any hierarchical (distancing and valorized) distance. As a distanced image a subject cannot be comical; to be made comical, it must be brought close" (23). La estrategia narrativa de focalización que usa González coloca al pueblo de Llano Verde muy "cerca" para volverlo risible; la estrategia documental de Nieves mantiene a Seva distante y remota para volverla solemne y heroica. Discrepo aquí pues de la lectura heteroglósica-bakhtiana que ha hecho Myrna García Calderón del formato de compilación en su artículo "Seva o la reinvención de la identidad nacional puertorriqueña" (202-3).

${ }^{25} \mathrm{El}$ antagonismo entre la contrafiguración del 98 de Seva y el emplotment de La llegada se perfila con mayor claridad en los comentarios sobre el fenómeno "Seva" que el mismo José Luis González incluye en Nueva visita al cuarto piso (118-123). González da cuenta del ánimo con que le comunica a López Nieves su apreciación entusiasta de "Seva" como un relato cómico, desmitificador y efectista; López Nieves le asegura que su intención era generar, precisamente, efectos contrarios: orgullo, mitificación, contramemoria. La reacción desconcertada y el análisis subsiguiente que ocupan a González merecen citarse in toto por su doble insistencia en la pertinencia literaria y la irrelevancia ideológica del cuento: "Como bien me consta que no soy el único puertorriqueño en guerra con las concepciones conspirativas de la historia, pensé en un primer momento [...] que 'Seva' representaba un premeditado y elogiable intento de poner en evidencia la proclividad mitificante de muchos puertorriqueños comprometidos con la justa causa de la independencia nacional [...] [C]uando tuve ocasión de hablar con Luis sobre el asunto, me desconcerté de que él no se había propuesto lo que yo suponía, sino todo lo contrario, o sea crear un nuevo mito para fortalecer el orgullo nacional de los puertorriqueños[...] Finalmente concluí que la explicación del escándalo que suscitó la publicación de 'Seva' radicaba en la naturaleza literaria del texto [...] Dicho en otras palabras, la verdadera vocación de Luis pudo más que su equivocada intención ideológica y le obsequió, en aleccionadora compensación, un triunfo literario como el que él mismo probablemente no esperaba" (122). 


\section{MALDITO AMOR O BENDITOS AMERICANOS}

Otra obra de ficción publicada en los ochenta marcada por la revisión gonzaliana del relato nacional es la novela corta Maldito amor (1986) de Rosario Ferré. Por su cuidadosa representación de un país severamente bifurcado en dos castas socio-étnicas, la novela es tal vez la manifestación literaria más fidedigna de las ideas de "El país de cuatro pisos". A través de la saga desmitificada de la prestigiosa familia criolla-propietaria de la Valle, dueña de la Central Justicia en el condado sacarocrático de Guamaní, Ferré hace un recuento de los 54 años del territorio bajo el aparato colonial tutelar. Como González en La llegada, Ferré yuxtapone perspectivas en confrontación sexual, étnica, social e ideológica. Se alternan capítulos de una novela apologética y proceratista que el abogado criollo Hermenegildo Martínez redacta sobre la vida de su fenecido amigo, el prohombre y senador liberal Ubaldino de la Valle, con los testimonios escandalosos y antagónicos que éste recibe de distintos parientes y afiliados de Ubaldino (la sirvienta negra Titina; el rencoroso hijo Arístides; Laura, la viudad moribunda; y Gloria, la enfermera y supuesta amante mulata de Ubaldino). Tales testimonios, en los que se disputa tanto la herencia material de la familia como el saldo moral de la nación, dibujan un reverso siniestro al retrato ultra-idealizado que ha estado haciendo Don Hermenegildo de los de la Valle en su biografía novelada. Sin lograr un consenso o gestalt integradora, estos informes contradictorios exponen a Ubaldino como un político oportunista, un degenerado sexual, un independentista hipócrita $y$, a pesar de una disimulada "pureza de sangre", como hijo de un negro. ${ }^{26}$

Si es cierto por un lado que el caudal de eventos recreados en esta novela no concierne propiamente a los de la invasión del 1898, Maldito amor destaca uno de los momentos más importantes del régimen tutelar que González consideró como el "tercer piso" del edificio insular. Tal es la instalación de la Ley Jones en 1917, que tuvo el alegado propósito de aliviar la marginación política de la aristocracia criolla e incorporarla más activamente en la administración de la colonia, pero que más bien sirvió, según la novela, para recrudecer el desmantelamiento de su hegemonía residual en la industria azucarera. ${ }^{27}$ Es en torno a esta segunda fase del tercer piso que se organizan los capítulos de la novela genealógica de Don Hermenegildo. El tercer capítulo, titulado significativamente "El desengaño", detalla cómo la ciudadanía americana concedida a los puertorriqueños por la ley obliga la salida de los financieros peninsulares reacios a naturalizarse, dejando sin recursos prestatarios a la burguesía hacendada criolla que sufre entonces una mayor pauperización al vedárseles cualquier acceso a la órbita financiera metropolitana. La conversación de Julio Font con los banqueros españoles que saldan su bienes y empacan sus pertenencias para la vuelta a su país, desconfiados en que el nuevo Senado electivo represente un adelanto genuino para los intereses isleños (31-2); la deslumbradora e intimidante inauguración de la modernizada

\footnotetext{
${ }^{26} \mathrm{He}$ consultado para mi análisis de Maldito amor los artículos de María José Bustos Fernández y María I. Acosta Cruz sobre la novela.

${ }^{27}$ Para más detalles sobre las estipulaciones de la Ley Jones, sus precedentes y sus resultados, véase José Trías Monge (40-110). Concentrándose en la historia legislativa y las intrigas y prevaricaciones políticas, Trías Monge no abunda sobre las consecuencias de la ley en el orden económico como lo hace Ferré en su ficcionalización.
} 
Central Ejemplo por empresarios norteamericanos (32-7); y la prohibición de la entrada de propietarios criollos al National City Bank por los Infantes de Marina (37) ilustran cabalmente la desintegración del poder fisiocrático de los patricios bajo el régimen norteamericano, según arguye González. Son estas circunstancias las que aceleran la expropiación de tierras criollas e incrementan los predios latifundistas del ausentismo azucarero norteamericano. ${ }^{28}$

Esta brutal expropiación y rápido desclasamiento llevan al independentista resentido Don Hermenegildo a crear un mito paradisíaco y conservador de Guamaní como cornucopia agrícola antes de que la llegada de los americanos convirtiera la región en un "enorme embudo" infernal para vertir el "aterrador remolino de azúcar que vomita la Central Ejemplo" (11). Don Hermenegildo pinta un empalagoso cuadro romántico de sutil convivencia patriarcal bajo España, expurgándolo de tensiones étnicas o animosidades anticachacas, para poder demonizar más vivamente el desvalijamiento de los privilegios de su clase bajo la ocupación norteamericana. De esta forma, el abogado ejemplifica la gestación reaccionaria del "independentismo tradicional" que González enjuicia en El país. La circunvalación del alcance jurídico de la Ley Jones también informa la caracterización que hace Don Hermenegildo de Ubaldino de la Valle. Es a través de la invocación de estatutos de herencia del Código Español no abrogados por la ley Jones que el joven Ubaldino logra recobrar la Central Justicia antes de que ésta pase a manos extranjeras y hacerse de la reputación que lanzará su carrera como prócer independentista (61). Es también esta ley la que provee el reducido espacio político en que los hijos venidos a menos de la clase propietaria intentarán plantear un proyecto nacional de resistencia: Ubaldino se hace miembro destacado del Senado electivo, adquiriendo "los rimbombantes apodos de Caballero de la Raza, de Castelar Criollo, de Corazón de León” y Águila de Guamaní por su arenga patriótica (77). Pero los testimonios de Laura y Gloria contradicen este relato heroico de restauración patriarcal al revelar la colaboración tras bastidores de un Ubaldino traicionero y codicioso con los grandes intereses extranjeros en el Senado. ${ }^{29}$ Maldito amor retoma pues así la metáfora de la prostitución que en La llegada sirve para retratar el

\footnotetext{
${ }^{28}$ Sobre la "cañaverización de Puerto Rico" véase el capítulo de igual título en la Historia general de Picó (231-41), y el capítulo titulado “La época del cañaveral: Economía y sociedad, 1900-1930" en Scarano (582-90).

${ }^{29}$ Gloria a Titina: "Porque tu amado Niño [...] hubiese quizás muerto de independentista feliz, si al llegar a Senador la Central Justicia no se le hubiese vuelto de pronto un Potosí. [...] Muy pronto se dio cuenta de que era imposible conjugar la magnesia con la gimnasia, costear los cruceros a Europa, las cuadras de caballos de paso fino, las queridas y los Rolls Royce sin aliarse a los intereses de sus antiguos enemigos, los dueños de la Central Ejemplo. Por un lado defendía la independencia [...] mientras que por otro lado se oponía violentamente a la ley de las quinientas cuerdas, al salario mínimo y a la jornada de ocho horas de trabajo, medidas que hundían a Guamaní cada vez más en el hambre y la desesperación" (76-7). La prominencia de Ubaldino como paladín de la independencia, el mote de "Caballero de la Raza", su contradictoria colaboración con las grandes centrales azucareras, y el hecho de tener una esposa llamada "Laura" sugieren que Ubaldino es una disimulada ficcionalización anacrónica de José de Diego, probablemente influída por el desfavorable retrato que hace González de esta figura histórica como emblema de la duplicidad del independentismo tradicional (El país 31$3)$.
} 
oportunismo autonomista en el 98 ("Vámonos, niña", musita Casiana, "que de ahora en adelante habrá que ver quiénes semos las putas de este pueblo!" 133) y la extiende hacia el futuro, mostrando cómo el patriciado criollo se vuelve aún más burdelizado durante la etapa del independentismo corrompido de Ubaldino.

Maldito amor también se apropia de la noción gonzaliana de un país dividido verticalmente en dos naciones étnicas antagónicas (terratenientes blancos contra sirvientes de color) y detalla cómo la hegemonía norteamericana facilita el ascenso social de los ocupantes del primer piso al desalojar a los del segundo de sus propiedades. La temida contaminación del segundo piso por el primero se desata irrefrenablemente bajo el régimen tutorial. Gloria, la prostituta negra, puede hacerse enfermera profesional tomando cursos en la universidad; aunque al parecer este avance no la persuade a descontinuar sus procuraciones, aunque ya no está atada al burdel y logra reclamos sólidos en esferas sociales más altas como la de los de la Valle. A través de su matrimonio con doña Elvira de la Valle, el mulato Julio Font se une a las filas propietarias del país; aún cuando Don Hermenegildo camufla su proveniencia al representarlo como un catalán testarudo en su novela, tal hecho ya es evidencia de la disolución de la clase hacendada como unidad hispano-racial homogénea. Finalmente, la decisión de Laura de legar la Central Justicia a Gloria y a Nicolasito (el hijo bastardo y cuarterón de Gloria), simboliza la justa restitución del proyecto nacional a los verdaderos "dueños" del país (los del primer piso). Como Nieves, Ferré recicla y transfigura los personajes de La llegada, pero situándolos en una etapa avanzada de reestructuración social bajo el tercer piso. El Benítez liberal y pro-americano se torna en el Hermenegildo conservador y nacionalista; niña Engracia, la prostituta mulata, reaparece como Gloria; Quintín y Petronila se vuelven Néstor y Titina; la temerosa y desinformada esposa de Benítez se torna en la Laura de mayor carácter y visión histórica. Laura es capaz de tal temple ya que en su condición subalterna como mujer criolla desarrolla un entendimiento práctico de la debilitación y las hipócritas contradicciones de la aristocracia azucarera bajo el mando norteamericano. Tal como prescribe González en El país (36), las mujeres en el cuadro sinecdótico-transversal de Guamaní adquieren más autoridad en el pos-noveintaiocho.

Sin embargo, a pesar de dramatizar muchos de los postulados gonzalianos, observamos en Maldito amor una desviación del metarrelato de González en lo que respecta a la invalidación futura del tercer piso. Si bien Ferré reproduce en la novela los presupuestos de una relación conflictiva entre una nación mulata popular y otra criolla blanca y expone cómo la mujer y el negro adelantan a medida que retrocede el patriarcalismo criollo ante la penetración americana, la misma no adopta el tratamiento cómico de la "nueva" presencia que vemos explícitamente en La llegada e implícitamente en la ensayística de González. La conflagración homicida que Gloria provoca en la hacienda al final de la novela anula el índice de optimismo con que debe concluir toda comedia y parece descalificar el telos que exige el emplotment gonzaliano-la supervivencia de la nación afrocaribeña independiente y descolonizada. Más aún, al igual que Nieves pero con una intención ideológica contraria, Ferré prescinde de la ironización crítica que hace González de la invasión para recuperar una versión previa del 98 , no como épica de resistencia o castástrofe, sino como romance triunfal. 
Este misreading del independentismo de González se hace más palpable y visible en la traducción inglesa de la novela (Sweet Diamond Dust, de 1988), especialmente en dos de las cuatro extensas e inquietante adiciones que Ferré hace al texto, no sólo porque alteran la configuración del personaje más próximo a la posición autorial (Laura) sino porque invierten la orientación ideológica de la novela en español. ${ }^{30}$ Primero, de acuerdo a la intervención de Gloria en Maldito amor, Laura es una independentista con una mayor integridad moral y convicción política que las de su marido. ${ }^{31}$ En Sweet Diamond Dust, Laura pierde sus ideales patrióticos y, durante su "confesión" a Don Hermenegildo, pinta un retrato apologético de la generosidad y el civismo manifestados por los industriosos y avanzados norteamericanos hacia los isleños poco después de la ocupación. ${ }^{32}$ Laura destaca a través de su largo elogio (67-9) las mejoras técnicas y científicas implementadas justo tras la invasión por los extranjeros en la transportación, la salubridad, la educación, la infraestructura, las comunicaciones y la medicina para entonces trazar un cuadro fustigador e irrisorio del retraso social y técnico de la cultura hacendada criolla. Concluye declarando su orgullo de que "three of my daughters married these civilized men" (69), uno de los grandes anatemas de la otra Laura. ${ }^{33} \mathrm{Si}$ bien la apología de Laura está de acuerdo con la interpretación que hace González de la ocupación del 98 como un fenónemo modernizador, la misma también disuelve la ironía sardónica con la que González quiso liquidar en $\mathrm{La}$ llegada el mito excepcionalista de la supremacía norteamericana. En la versión inglesa de su novela, Ferré configura el relato del 98 como un romance de la benignidad para recuperar una noción del invasor-como-redentor que atenta agresivamente contra la anulación que González quiso hacer de la misma con su retrato satírico del imperialista Mackintosh. La visión romántica de los norteamericanos que termina apoyando Sweet Diamond Dust

\footnotetext{
${ }^{30}$ Por el momento, Janice A. Jaffe ha sido quien ha analizado con más rigor y penetración crítica las múltiples transformaciones que sufre el texto de Maldito amor para convertirse en Sweet Diamond Dust. Partiendo de una lúcida aplicación de teorías de traducción de orientación feminista y de los propios ensayos de Ferré, Jaffe interpreta metáforicamente el tipo de traducción intercultural "infiel" y "licenciosa" que hace Ferré de su propia obra de ficción como una forma positiva de "prostitución" literaria. Indica Jaffe que "in certain instances [in the translation] Ferré modifies the anti-Yankee tone of the Spanish text" (76).

31 "Doña Laura era independentista, y por eso su hijo preferido fue Nicolás [también independentista], mientras se peleaba todo el tiempo con sus otros hijos [que se casan o simpatizan con norteamericanos]. Al final terminó odiando a Don Ubaldino" (76). Se deduce que tal odio responde tanto a las infidelidades de Ubaldino como a su traición a la causa independentista.

${ }^{32} \mathrm{El}$ siguiente pasaje sintetiza la nueva opinión de Laura: "The foreigners were dynamos, men of unflagging action; they were all young and handsome, engineers, architects, doctors, energetic entrepreneurs who believe they could transform the world and bring us the blessings of progress. They were brimming with idealism: they didn't have to civilize the world, they themselves were perfectly happy in their own land, where they had built marvelous cities and practically wiped out poverty, and yet they believed it their duty to better the destiny of others" (67).

${ }^{33} \mathrm{La}$ Laura de Maldito amor manifiesta su poca simpatía por los norteamericanos al querer desheredar a sus hijas para evitar que la Central Justicia pase a manos de sus esposos gringos: "[A] mí los extranjeros no me podrán quitar jamás la Central Justicia. Porque aunque mis hijas se casaron con los dueños de la Ejemplo; aunque un hijo me salió cipayo y el otro me lo arrebató la muerte, ahí me quedan todavía Gloria y Nicolasito" (70).
} 
incurre en la misma ausencia de ironía que manifiesta "Seva" en su interpretación paranoica de la invasión.

Finalmente, Ferré también traiciona el lugar privilegiado que ocupa el primer piso mulato en el pensamiento de González cuando hace a Laura, en otra extensa inserción a su testimonio en la versión inglesa, redefinir a Guamaní y al país no como una isla-tierra con una larga historia de sedimentación y conformación social y humana (i.e., de "pisos" étnicos), sino como un puerto marítimo; es decir, como un espacio abierto de tránsito constante, despoblación e impermanencia demográfica. ${ }^{34}$ Es por acatar esta lógica desterritorializadora (y no por querer legar la patria-tierra-hacienda, al fin liberada de los intereses foráneos hacendados y norteños, a sus merecidos "dueños" después de una espera de siglos, como en Maldito amor) que Laura en Sweet Diamond Dust impone condiciones a la herencia de Gloria. Laura estipula que Gloria venda la tierra heredada para que con el ingreso financie un flujo migratorio bidireccional de trabajadores, hacia dentro y fuera de la isla. ${ }^{35}$ A través de esta celebrada diasporización del espacio isleño, Ferré anula el principio de soberanía territorial que González postulaba como resolución al proceso nacional mulato iniciado en el siglo dieciocho.

Ferré ha reconfirmado su desligación violenta con el metarrelato independentista de González al decidir orientar su ficción a un público metropolitano de habla inglesa a partir la redacción de The House on the Lagoon (1994), y al pronunciarse como partidista de la anexión del país dentro de un Estados Unidos "multicultural" en el que no se perdería la identidad hispana. ${ }^{36}$ La conversión de Ferré de militantemente pro-gonzaliana en Maldito amor a anti-gonzaliana en Sweet Diamond Dust merece un riguroso escrutinio, pero cabría proponer que, antes de cambiar sus banderas, Ferré había coincidido con González sólo hasta cierto punto. Su discrepancia con la teleología de El país ya se manifiesta en un cuento de los ochenta ("La extraña muerte del Capitancito Candelario", incluído en Maldito amor) en donde parece proponer que la dialécta metrópolis-isla no ha logrado deshacer del todo el poder de la aristocracia venida-a-menos, y que los descendientes de esta clase han resistido lo que González describió como proceso de "plebeyización". Por lo tanto, una

\footnotetext{
${ }^{34}$ Laura II: "I foresee a time when all this rivalry and struggle for our fertile valley between the local landowners and northern invasors will be but a legend whispered by the wind, a picturesque romance of the past. Because it's not our land but our port, the beautiful shimmering bay of Guamani that will one day make our fortunes, as the land becomes less and less important to all of us. It's our island's destiny to become the gate to South as well as to North America, so that on our doorsill both continents will one day peacefully merge into one. And it's for this reason that I'm set on leaving Diamond Dust to Gloria and Nicolasito, because they are the children of that port, their unbribable tribal offspring" (75-6). Laura pasa a feminizar la imagen del puerto abierto, asociándola a la sexualidad promiscua de Gloria cuando se prostituye en los muelles.

${ }^{35}$ Laura II: "And so I have instructed Gloria to sell our land progressively, piece by piece, to aid those who have already begun to emigrate to the mainland by thousands, fleeing from the hell of the sugar plantations $[. .$.$] as well as to those who will undoubtedly return, perhaps after spending half their lives$ reaping California grapes [...] but with enough money in the pockets to buy a piece of their lost paradise back" (77).

36 "Puerto Rico, U.S.A." 17. Cabe preguntarnos cuál hubiera sido la reacción de González ante tal cambio de parecer.
} 
independencia unilateral propendería no en la victoria del primer piso sobre el segundo, sino en el divisionismo de una sangrienta e incontenida guerra civil, esa que media entre los "rockeros" y los "salseros" en el relato. Luce que el anexionismo de Ferré es una posición tomada para prevenir la conflagración social que se presiente en la conclusión de casi todas sus novelas, conflagración que no figura en el metarrelato de El país. Recurriendo a la terminología bloomiana, diríamos que Ferré lleva a cabo un clinamen, una desviación que corrige el tendencioso optimismo del movimiento unidireccional en la teleología de González. ${ }^{37}$

\section{CRUZANDO LA BAHÍA DE GUÁNICA O LA BANALIZACIÓN DEL 98}

El extenso diálogo entre la obra de Edgardo Rodríguez Juliá y la de José Luis González ha sido reconocido por ambos autores en varios momentos pero nunca más abiertamente que en la dedicatoria que le hace Juliá a González, "el gran ausente", en Las tribulaciones de Jonás. ${ }^{38}$ Todos los escritos tempraneros de Juliá ponderan la coexistencia conflictiva de las dos naciones isleñas planteadas por González en lo que Malena Rodríguez Castro ha llamado, en su lectura de las "crónicas mortuarias" de Juliá, el "país de muchas tribus" (87). A través de estas crónicas, próceres en ascendencia o decadencia oriundos del segundo piso confrontan la pujanza afirmadora de los miembros del primero: Víctor Pellot sirve de contrapunto al Muñoz Marín de Las tribulaciones; Ismael Rivera alterna con Hernández Colón en El entierro de Cortijo. Sin embargo, en trabajos más tardíos como "El cruce de la Bahía de Gáunica y otras ternuras de la medianía", Juliá lleva la crítica que hace González del discurso independentista tradicional a extremos que rayan en el nihilismo y el desinterés. En "El Cruce", la revisitación del 98 no se hace para pronosticar la independencia del país popular-mulato; esta crónica más bien presenta un testimonio carnavalizado de la asimilación casi total del primer piso por un consumismo desencializador.

Relato autobiográfico de simplicidad engañosa, "El cruce" es una complejísima narración en la que el ensoberbecido autor simula detallar con esmero un evento banal que carece de un significado histórico "serio". El autor describe su participación del 25 de julio de 1983 en un concurso atlético: el "cruce" a nado a través de la dicha bahía que es auspiciado semianualmente por una asociación de comerciantes del pueblo. En medio de un gentío bruegheliano en donde se destaca bakhtianamente lo digestivo(frituras, panzas descomunales, borracheras), lo excrementicio (orinales, letrinas, basureros) y lo reproductivo (multitud de niños diabólicamente traviesos, innumerables bolsas de pañales desechables), el autor

37 "Clinamen [...] is poetic misreading or misprision proper [...]. A poet swerves away from his [en este caso, "her"] precursor, by so reading his [ibid] precursor's poem as to execute a clinamen in relation to it. This appears as a corrective movement in his [ibid] own poem, which implies that the precursor poem went accurately up to a certain point, but then should have swerved, precisely in the direction that the new poem moves" (Bloom 14).

${ }^{38}$ En su ensayo "A mitad de camino", Juliá da cuenta detenida de su "afición" y mentorado bajo José Luis González, incluyendo su relación corresponsal durante el período de redacción de la Crónica de Nueva Venecia (129-34). González consigna su amistad con Rodríguez Juliá, Ferré y López Nieves en varias páginas de Nueva visita. 
reflexiona sobre las tribulaciones de la "medianía"(el middle age desvirilizador), implicando que el alocado cruce es un ritual ansioso para satisfacer su vanidad masculina. Hiperconciente de las limitaciones de su cuerpo y manejando diestramente los tecnicismos del lenguaje playero ("resaca", "marullo", "brazada"), Juliá da cuenta de su intento por lograr un heroísmo crepuscular. Aunque el autor reconoce abiertamente este rito como un patético "fracaso total" (43), el ejercicio se justifica cuando logra alcanzar durante la carrera un momento de pleno logro y serenidad que lo rescata brevísimamente de una vida cotidiana abrumadora y ensordecedora (40-2).

Pero, más que una meditación melancólica o anecdótica sobre el envejecimiento masculino, "El cruce" es una profunda reflexión sobre el impacto que ha tenido el cambio hegemónico norteamericano tanto en la memoria colectiva del país como en su orden social y económico. Es decir, "El cruce" es otra reescritura del metarrelato planteado por González ya que cada 25 de julio Guánica se torna en lo que Juliá llama un "palimpsesto histórico" (25). La fecha emblemática del desembarco de las tropas norteamericanas en 1898 ha motivado a través del siglo eventos, conmemoraciones y protestas dispares de gran consecuencia ideo-política: el Partido Nacionalista bajo Albizu Campos escogió este día en 1932 para escenificar en Guánica la más furibunda condena del imperialismo americano en su calendario político y hacer los pronunciamientos más importantes de su plataforma; el Partido Popular Democrático bajo Muñoz Marín escogió este día en 1952 para oficiar la fundación del Estado Libre Asociado; y fuerzas policiales encubiertas escogieron este día en 1978 para el entrampamiento y asesinato de dos jóvenes independentistas en el complejo de comunicaciones del Cerro Maravilla para demonizar y escarmentar el radicalismo clandestino. ${ }^{39}$ La crónica escenifica pues cómo se entrecruzan y se sobreimponen, cual palimpsesto histórico, celebraciones y manifestaciones de las más discordantes ideologías durante este día en Guánica: las ceremonias de agresiva profesión anexionista compiten con los desfiles ostentosos y contentos del status quo autonomista; las festividades alcoholizadas y ruidosas de las fiestas patronales ahogan la beligerante protesta anti-yanqui de la espartana tribuna independentista. El texto mismo simula esta superposición palimpsestual y ucrónica de metarrelatos discordantes e historicidades encontradas al prologar la crónica con una recreación imaginaria del cruce originario: el del acorazado Gloucester, cuya imponente silueta y tronantes armamentos alteran el paisaje apacible del malecón (10-14). En este desembarco pacífico y banal que evoca Juliá se comienza a rearmar el espacio sociopolítico de acuerdo a la interpretación gonzaliana. Juliá recuerda cómo los norteamericanos nombraron a Simón Mejil, un "negro alto y fuerte" y "único habitante que había permanecido en el poblado", jefe de la policía mientras que "llaman a presencia" al alcalde vizcaíno Don Agustín Barrenechea para izar la bandera americana en su propia "casa-alcaldía" (13). Al destacar un episodio donde la nueva hegemonía promueve en la escala social a un miembro del primer piso para hacerlo "ostentador del poder del estado" y reduce a otro del segundo piso a ser detentador de "una precaria autoridad civil", (13) Juliá hace de este prólogo un resumen concentradísimo de las tesis expuestas en El país de cuatro pisos y La llegada.

\footnotetext{
${ }^{39}$ Para más detalles sobre las muertes de Carlos Enrique Soto Arriví y Arnaldo Darío Rosado, el escándalo y la investigación de los eventos de Cerro Maravilla, véase el libro de Manny Suárez, Requiem on Cerro Maravilla.
} 
Al proyectar telescópicamente la crónica hacia el presente, Juliá también adopta la actitud crítica de González respecto a la interpretación del 98 como catástrofe y trauma hecha por el "independentismo tradicional". En su representación desacralizada del líder nacionalista Juan Antonio Corretjer, Julia inyecta la suspacia de González respecto al discurso polarizador que busca demonizar la invasión norteamericana; la crónica termina recalcando la marginalidad e irrelevancia de este tipo de independentismo en el presente cuadro histórico. En su ambivalente retrato de un Pedro Juan Soto llevado a la incoherencia por la muerte de su hijo Carlos Enrique en el Cerro Maravilla, Juliá también reflexiona, como hace González con el albizuísmo, sobre la dolorosa inutilidad de los gestos heroicos o voluntaristas que invariablemente desembocan en martirios con poca capacidad de convocatoria.

Sin embargo, "El Cruce" no confirma todos los postulados gonzalianos: la proyección al presente también contradice la teleología afirmativa de González. La gran confianza que tuvo González en la supervivencia, por encima de las influencias foráneas, de una puertorriqueñidad auténtica en el sector popular se ve sardónicamente anulada por la quevediana y "misantrópica" representación que hace el distanciado cronista de un vulgo grosero y sugestionado por el consumo y el comfort que provee la dependencia en el sistema económico americano. La "nación popular" exaltada por González luce aquí obsesionada por lujosos productos importados, entre los que sobresalen numerosos vehículos de motor (Go Karts, motoras Harley Davidson, botes de carreras) que inducen en el paisaje de la bahía una incongruencia análoga a la del Gloucester de la invasión. En lugar de la fraternidad afrocaribeña y la aguda conciencia nacional vislumbrada por González en el dicho sector, este primer piso sólo es capaz de manifestar una "ociosa" visión cosmética, emblématica y comercial de la identidad cultural, con "sombreritos de paja que dicen Puerto Rico" (23) o niños disfrazados para marchar en la parada como Tío Sam y La Isla del Encanto (28).

En este reemplotment, la ironía de González, siempre atenta a la comicidad de los desencuentros para luego proponer su resolución en la nación-estado socialista, se torna en la mordacidad de Juliá, quien sólo puede reconocer una inercia ateleológica y antihistórica en la irreconciliación insuperable y ruidosa de ideologías, pisos, etnias y tribus . Aunque Juliá proclame algo burdamente que esta mordacidad surge del "lento sapo" de su "misantropía" (23), la misma también manifiesta lo que el título y la conclusión señalan como un tipo de "ternura" o "compasión" que valoriza en cierto grado la atomización carnavalesca al desdecir con insistencia las viejas nociones traumáticas de la catástrofe y la tragedia. Esta "ternura" hace que el discurso de Juliá no se vuelva del todo ajeno a la visión de González; es decir, de la ironización que hace González del 98 Juliá pasa a hacer una banalización en la que se descarta cualquier noción demonizadora, paranoica o reaccionaria de la llegada de los "bárbaros americanos" al mostrarse que cualquier intento recio de explotación política o económica de su parte será contramanipulada por la astucia o jaibería del primer piso e integrada como otra carroza en su carnaval. De hecho, en cuanto a la representación del invasor, el rol del supremacista e intolerante Coronel Mackintosh de $L a$ llegada lo asume aquí el solidario profesor retirado William Storyck, judío transterrado y transculturado, que acompaña a Juliá en el cruce en un ritual de amistad. Al contrario de MacKintosh, Storyck se ha aclimatado felizmente al territorio tropical, y resulta tan bondadoso e inofensivo que es imprecado insistentemente por niños traviesos, tal como los 
voluntarios novatos en La llegada. Podríamos aventurar que, según las categorías revisionistas de Bloom, Juliá ejecuta una kenosis en la que, en el acto de auscultar su "medianía", autoparodiarse salvajemente y disolver con irreverencia tanto su autoridad como la de otros escritores ilustres en el relato (Corretjer, Soto), también substrae la autoridad canónica de las ideas de González. ${ }^{40}$

\section{CONCLUSIÓN: LA MUERTE DEL NARRADOR Y LOS ARCHIVOS DE LA OPACIDAD}

A pesar de sus diversos módulos y propósitos, todas las reescrituras ochentistas del metarrelato gonzaliano del 98 coinciden al no suscribir a la propuesta de una teleología nacional y gradualista en la que el primer piso del territorio ande irrevocablemente hacia la realización de un estado independiente con una identidad caribeña. También convergen al optar por no recurrir, en el orden formal y técnico, a los métodos imago-narrativos que González accede para ilustrar su visión. Tanto Juliá como Ferré y López Nieves evitan usar la trabajada persona del narrador omnisciente, objetivo y focalizado que González ensambla a partir de recursos tomados de la novela moderna(Hemingway, Faulkner, Woolf, Proust, Joyce) y que fue su aporte técnico más célebre. Nieves, Ferré y Juliá adoptan en vez recursos posmodernos anti-autoriales tales como el pastiche, la simulación, la parodia, el collage textual, la metaficción, el subjetivismo y el sentimentalismo para renunciar a cualquier reclamo de omnisciencia en su escritura. En lugar de erguirse como narrador en tercera persona de su invasión inventada, López Nieves prefiere presentarse como un ordenador de documentos que presumen otra(s) autoría(s). Tanto en Maldito amor como en The House on the Lagoon no hay una presencia o voz autorial per se; estas novelas se ofrecen como compilaciones de manuscritos previos compaginados para dramatizar la confrontación de relatos discrepantes. Si es cierto que al yuxtaponer los capítulos y anotaciones de la escritura patriarcal de Don Hermenegildo con testimonios subalternos o demitificadores (Titina, Arístide, Laura y Gloria) Ferré logra desautorizar el discurso oficialista en una forma que bien hubiera complacido a González, tal diseño tampoco se resuelve en una gestalt final que pueda permitirle al lector una versión incontrovertida de los hechos históricos o anecdóticos. Inversamente, la perspectiva ultrasubjetiva en las crónicas de Juliá - en las que toda la copiosidad de referencialismo histórico pasa filtrada por el estrecho embudo del ánimo autorial — descarta toda presunción de la objetividad que autoriza al narrador de La llegada a fabricar su coreografía de perspectivas y voces por encima de los prejuicios de sus personajes

Esta deflación de la prepotencia de una voz autorial objetiva y la pérdida consecuente de la transparencia de los hechos narrados es síntoma, creo, de una transformación en la relación entre imaginario y archivo que ocurre en Puerto Rico a partir de los setenta pero que se manifiesta contundentemente en la narrativa ochentista. El desarrollo del uso de la

\footnotetext{
40 "Kenosis $[\ldots]$ is a movement towards discontinuity with the precursor [...] The later poet, apparently emptying himself of his own afflatus, his imaginative godhood, seems to humble himself as though he were ceasing to be a poet, but this ebbing is so performed in relation to a precursor's poem-ofebbing that the precursor is emptied out also, and so the later poem of deflation is not as absolute as it seems" (14-5).
} 
tercera persona en la novela europea deriva en parte de la autonomía y la objetivación que va asumiendo la propia narrativa histórica en el siglo diecinueve. Ambas omnisciencias la que permiten a Hegel hacer visible la dirección de la historia y a Joyce y a Woolf hacer visibles las mentes de sus personajes-dependen de la presunción de un Archivo histórico legible, accesible y corroborable donde se pueda pasar juicio sobre todo dato disputado. El tipo de omnisciencia que el narrador de González introduce en la ficción histórica puertorriqueña parte de la premisa de un Archivo transparente y verificable en cuya recuperación y reconstitución labora el intelectual tercermundista; toda la carrera de González se basó en el principio de que una historia emancipadora podría ser finalmente descifrada a partir de la interrogación rigurosa y científica de fuentes hegemónicas e imperiales. Tras los desencuentros del telos dialéctico en la posmodernidad (y la potente impresión que dejó en el país el encubrimiento y la desinformación oficial llevada a cabo en torno a los asesinatos en el Cerro Maravilla), la presunción de un Archivo transparente, no-intervenido, se vuelve insostenible para el imaginario ochentista. Para tal imaginario tal Archivo adolece de sospechosas manipulaciones y ocultamientos patriarcales, de supresiones imperiales conspirativas, y resulta ser sólo un emisor de ficciones ideológicas. La verdad histórica deja de ser un propósito narrativo: a pesar de mostrar cierta referencialidad historicista, tanto Ferré como López Nieves se desentienden de cualquier fidelidad sistemática al Archivo y tergiversan a gusto el récord o la cronología en aras del efectismo o la fuerza estética de la narración. Sus personajes "históricos" son símbolos pastichados cuya complejidad no se resuelve buscando una figura correspondiente en los libros de texto. En sus novelas históricas Juliá también manipula el Archivo a su antojo; sus crónicas, por otra parte, lucen como una propuesta por un tipo de documentación anti-oficial del evento en donde el alto grado de subjetivismo previene cualquier intento de manipular los datos según una configuración ideo-histórica interesada.

Opino también que González llegó a percatarse de la terrible opacidad del Archivo hacia el final de su carrera. Por eso, decidió renunciar a las pretensiones objetivistas de la técnica narrativa moderna y encomendó sus últimos esfuerzos creativos a la fluidez intersticial, subjetiva, híbrida y multiforme de la crónica posmoderna, género predilecto por sus discípulos de la Generación del Setenta. Echando a un lado las formas del ensayo y la novela, en Nueva visita al cuarto piso y La luna no era de queso, González accede a los dispositivos analítico-discursivos de la crónica y el testimonio personal tan caros a Rodríguez Juliá, Magali García-Ramis, Ana Lydia Vega y otros “jóvenes”. Este cambio discursivo muestra que, en cierto grado, González reconoció lo equivocado que fue catalogar La llegada como una crónica con "ficción" (según reza el subtítulo). Más que una narración histórica sucedánea y corroborable (como se supone sea toda crónica tradicional, según el epígrafe de Herrera/Cardenal que encabeza la novela), el texto es, a todas luces, una novela de factura moderna, que echa mano de todas las técnicas de la omnisciencia. Más que una "ficción" en la cual las comillas sirven para desmentir la ficcionalidad, La llegada es, sencillamente, una ficción: una artesanal creación de la "historia" con ínfulas objetivistas que se sostiene sobre la posibilidad de un presunto Archivo poscolonial que tal vez no habrá de existir. Con su obras tardías, González reconoce la necesidad de recolocar las comillas, de mostrar que, tanto La llegada como su obra entera, son una "crónica" con ficción. Al reformar así su posición autorial, González resulta ser su propio y primer enterrador. Al 
saberse adaptar a los nuevos módulos discursivos, reaparece ahora resucitado, imborrable reflejo en las obras de su progenie rebelde.

\section{BiBLIOGRAFÍA}

Acosta, Ivonne, ed. La palabra como delito: los discursos por los que se condenaron a Pedro Albizu Campos, 1948-1950. Río Piedras: Editorial Coltural, 1993.

Acosta Cruz, María I. "Historia, ser e identidad femenina en 'El collar de camándulas' y 'Maldito amor' de Rosario Ferré”. Chasqui 19/2 (1990): 23-31.

Albizu Campos, Pedro. Obras escogidas, 1932-1936. Vols. 1 y 2. Recopilación, introducción y notas por J. Benjamín Torres. San Juan: Editorial Jelofe, 1975, 1981.

Bakhtin, M. M. "Epic and Novel”. The Dialogic Imagination: Four Essays. Michael Holquist y Caryl Emerson, trads. Austin: University of Texas Press, 1981. 3-40.

Blanco, Tomás. Prontuario histórico de Puerto Rico. Séptima edición. Río Piedras: Ediciones Huracán, 1981.

Bloom, Harold. The Anxiety of Influence. A Theory of Poetry. Oxford: Oxford University Press, 1973.

Brown, Wenzell. Dynamite on our Doorstep. Puerto Rican Paradox. New York: Greenberg, 1945.

Bustos Fernández, María José. "Subversión de la autoridad narrativa en Maldito amor de Rosario Ferré". Chasqui 22/2 (1994): 22-9.

Daroqui, María Julia. Las pesadillas de la historia en la narrativa puertorriqueña. Caracas: Monte Avila Editores, 1990.

Díaz Quiñones, Arcadio. Conversación con José Luis González. Río Piedras: Ediciones Huracán, 1976.

"Isla de Quimeras: Pedreria, Palés y Albizu". Revista de Crítica Literaria Latinoamericana 23/45 (1997): 229-46.

"Recordando el futuro imaginario: la escritura histórica en la década del treinta". Sin Nombre 14/3 (1984): 16-35.

Fernández Retamar, Roberto. Calibán: Apuntes sobre la cultura en Nuestra América. 1972. México: Editorial Diógenes, 1974.

Ferré, Rosario. Maldito amor. México: Joaquín Mortiz, 1984. Sweet Diamond Dust. Traducción de la autora. New York: Plume/Penguin Books, 1996. "Puerto Rico, U.S.A.". New York Times (19 de marzo de 1998). The House on the Lagoon. New York: Farrar, Straus, and Giroux, 1995.

Friedel, Frank. The Splendid Little War. Boston: Little, Brown, and Company, 1958.

García Calderón, Myrna. "Seva' o la reinvención de la identidad nacional puertorriqueña”. Revista de crítica literaria latinoamericana 20/39 (1994): 199-215.

Gil, Carlos. El orden del tiempo. San Juan: Ediciones PD Posdata, 1994.

González, José Luis. El pais de cuatro pisos y otros ensayos. Río Piedras: Ediciones Huracán, 1980. La llegada (Crónica con “ficción”). Río Piedras: Ediciones Huracán, 1980. 
Nueva visita al cuarto piso. Santurce: Libros del Flamboyán/Fundación Educativa Ana G. Méndez, 1986.

Balada de otro tiempo. Río Piedras: Ediciones Huracán, 1978.

La luna no era de queso: memorias de infancia. Río Piedras: Editorial Cultural, 1988.

"Puerto Rico en la hora cero". Revista de la Universidad de México 34/3 (noviembre 1979): 29-31.

"Puerto Rico: Una nueva mirada a un nuevo país". Nuevo Texto Crítico 2/3 (1989): 59-69.

"Plebeyismo y arte en el Puerto Rico de hoy". El país de cuatro pisos yotros ensayos. 1980. Río Piedras: Ediciones Huracán, 1981.

Harding Davis, Richard. The Cuban and Porto Rican Campaigns. New York: 1898. Citado por Picó, 66-67.

Hostos, Eugenio María de. Textos. Una antología general. Prólogo, selección y notas de José Luis González. México: Secretaría de Educación Pública/UNAM, 1982.

Irizarry Díaz, Guillermo B. "El 98 en La llegada de José Luis González: las trampas de la historia". Revista Iberoamericana LXIV/184-185 (julio-diciembre 1998): 397-411.

Jaffe, Janice A. "Translation and Prostitution: Rosario Ferré's Maldito amor and Sweet Diamond Dust". Latin American Literary Review 23/46 (julio-diciembre 1995): 6682.

López Nieves, Luis. Seva: Historia de la primera invasión norteamericana de la isla de Puerto Rico ocurrida en mayo de 1898. San Juan: Editorial Cordillera, 1984.

Luque de Sánchez, María Dolores. La ocupación norteamericana y la la ley Foraker (La opinión pública puertorriqueña). Río Piedras: Editorial Universitaria, 1980.

Maldonado Denis, Manuel. "En torno a 'El país de cuatro pisos': aproximación crítica a la obra sociológica de José Luis González”. Casa de las Américas XXIII/135 (noviembrediciembre 1982).

Manrique Cabrera, Francisco. Historia de la literatura puertorriqueña. Río Piedras: Editorial Cultura, 1971.

Marqués, René. Los soles truncos. Teatro. Río Piedras: Editorial Cultural, 1986.

Morales Carrión, Arturo. Puerto Rico: A Political and Cultural History. New York: W. W. Norton \& Company, 1983.

Natal, Carmelo Rosario. Puerto Rico y la crisis de la guerra hispanoamericana (18951898). Río Piedras: Editorial Edil, [1975] 1989.

Pabón Ortega, Carlos E. "El 98 en el imaginario nacional: Seva o la 'nación soñada"”. La Nación Soñada: Cuba, Puerto Rico y Filipinas ante el 98. Consuelo Naranjo, et. al. ed. Madrid: Ediciones Doce Calles, 1996. 547-57.

Pedreira, Antonio S. "Insularismo". Obras I. 1934. San Juan: Instituto de Cultura Puertorriqueña, 1970. 13-176.

Picó, Fernando. 1898: La guerra después de la guerra. Río Piedras: Ediciones Huracán, 1987. Historia general de Puerto Rico. Río Piedras: Ediciones Huracán, 1986. 
Ramos, Josean. "Crónica: Seva: un sueño que hizo historia". Luis López Nieves, Seva: historia de la primera invación norteamericana de la isla de Puerto Rico ocurrida en mayo 1898. San Juan: Editorial Cordillera, 1984. 57-87.

Rodríguez Beruff, Jorge. Política militar y dominación: Puerto Rico en el contexto latinoamericano. Río Piedras: Ediciones Huracán, 1988.

Rodríguez Castro, María Elena. "Memorias conjeturales: las crónicas mortuarias". Las tribulaciones de Juliá. Juan Duchesne Winter, ed. San Juan: Instituto de Cultura Puertorriqueña, 1992.

Rodríguez Juliá, Edgardo. "A mitad de camino". Imágenes e identidades: el puertorriqueño en la literatura. Asela Rodríguez e Laguna, ed. Río Piedras: Ediciones Huracán, 1985. El cruce de la Bahía de Guánica. San Juan: Editorial Cultural, 1989. Las tribulaciones de Jonás. Río Piedras: Editorial Huracán, 1981. El entierro de Cortijo. Río Piedras: Editorial Huracán, 1983.

Rosario Natal, Carmelo. Puerto Rico y la Crisis de la Guerra Hispanoamericana (18951898). 1975. Río Piedras: Editorial Edil, 1989.

Scarano, Francisco. Puerto Rico. Cinco siglos de historia. Bogotá: McGraw-Hill Interamericana, 1993.

Sotomayor, Aúrea. "Apuntes de un cronista: La llegada". Hilo de Aracne. Literatura puertorriqueña hoy. San Juan: Editorial de la Universidad de Puerto Rico, 1995. 257 64.

Steward, Julian H., et.al. The People of Puerto Rico: A Study in Social Anthropology. Urbana: University of Illinois Press, 1956.

Suárez, Manuel. Requiem on Cerro Maravilla. The Police Murders in Puerto Rico and the U.S. Government Coverup. Mapplewood, NJ: Waterfront Press, 1987.

Trías Monge, José. Historia constitucional de Puerto Rico. Vol. II. Río Piedras: Editorial de la Universidad de Puerto Rico, 1981.

White, Hayden. Tropics of Discourse: Essays in Cultural Criticism. Baltimore: Johns Hopkins University Press, 1978.

The Content of the Form: Narrative Discourse and Historical Representation. Baltimore: Johns Hopkins University Press, 1987.

Zeno Gandia, Manuel. Redentores. Obras completas II. 1925. San Juan: Instituto de Cultura Puertorriqueña, 1973. Facsímil. 
